\title{
The Transformation from Dentist to Healthcare Provider
}

\author{
James Burke Fine* \\ College of Dental Medicine, USA
}

Submission: July 24, 2017; Published: November 28, 2017

*Corresponding author: James Burke Fine, DMD, Senior Associate Dean for Academic Affairs, College of Dental Medicine, 630 West 168 th street, PH7 W-308A, New York, New York 10032, Tel: 212-305-5908; Email: jbf1@columbia.edu

\section{Abstract}

The changes in the healthcare system and the focus of recent research have created an opportunity for dentistry to finally integrate the profession into the overall healthcare of the patient. Technology, social media and big data will allow this change if seized by the profession to be rapid. This opinion piece provides the rationale and academic pathway for this approach to becoming oral healthcare providers in the evolving healthcare system

Keywords: Oral health care; Periodontal disease; Inflammation; Caries; Cancer; Education

\section{Perspective}

The transformation from dentists to oral healthcare providers or healthcare provider is an ongoing discussion in many academic institutions. The public identity of dentists and dentistry has been long established and held in high esteem. This image is reinforced daily through everything from television advertisements to social media. The American Dental Association also helps sustain the identity of the sole practitioner as the last hold out against what is perceived by the public as a healthcare system dominated by Big Pharma, Insurance companies and corporate medicine. The public realizes that forces beyond their control dictate the physician they see. Optometry and pharmacy are now strictly corporately managed components of a complex healthcare system. This image of dentistry may be eroding faster then we think. An article in the Washington Post on July 1st 2017 by Mary Jordan "The unexpected political power of Dentistry" describes the ADA continuous lobbying of Congress to maintain dentistry's current autonomy despite a rapidly changing healthcare environment, declining public image and possibly unsustainable economic position.

The future then becomes one of embracing the changes in healthcare or staying the course. Google and Apple are entering the healthcare market through big data and information technologies. Amazon will eventually be in the dental supply business. There will be a transformative opportunity in dentistry that will be either controlled by the profession or by corporate entities. Dental education and continuing education is now wrestling with the same dilemma. Do we continue to educate for the current model of the one / two dentist sole practitioner being reimbursed by the procedure or for the future oral healthcare provider who is part of the overall healthcare system? Dental Service Organizations (DSOs) are now expanding but still does not dominate the dental market. The DSOs also have not integrated into the overall healthcare system. Over a decade has passed where the distant effects of oral inflammation has been shown to complicate other medical conditions and systemic diseases. In certain situations like cardiovascular disease oral inflammation is a risk factor for myocardial infarct and stroke [1]. The opportunity is now here for the co-morbidly of oral and systemic diseases to be treated as part of the overall healthcare of the patient. The use of an electronic health record (EHR) that is designed to capture both the medical and dental history and treatment of the patient can now be used in group practices that have physicians and dentists working in tandem. Several immediate benefits will be realized starting with a better heath care outcome for individual when the treatment plan includes improving both the medical and dental health. Next, the more comprehensive capture of "big data" from the EHR will provided for better evidenced based medicine and dentist in the future. Insurance companies will eventually reimburse dentistry and medicine for maintaining health and preventing the onset of oral and systemic diseases. There is evidence that improved vitamin $\mathrm{D}$ and calcium levels will benefit both systemic and oral health. So either the dentist or physician can provide this straightforward approach to health maintenance [2]. 
Dental school education and continuing education does need to continue to focus on digital dentistry, implants and esthetics but it now needs to be balanced with more focus on co-morbidity of diseases and oral health. This will require more courses on medicine for dentists and a shift in practice to helping patients make healthy lifestyle choices. This would include weight loss to decrease risk of developing diabetes. The oral health benefit comes with controlling obesity and diabetes that increase the risks for oral inflammation [3].

Genetics and precision medicine is now influencing all parts of healthcare. Periodontal disease has a genetic component and will be the center of precision dentistry that will allow for individualized care. The opportunity with all the rapid advances in technologies and data collection will now allow for a true shift in the dental profession to be a consistent component of the evolving healthcare system in the United States. Physicians will need to embrace the collaboration with dentists and recognize that oral health plays a role in even serious illness like cancer and eventually premature death [4].

Dentistry also must evolve to manage dental conditions in a manner more consistent with medical treatment. This includes utilizing therapies beyond mechanically managing the oral diseases of caries and periodontal conditions through novel approaches of altering the flora that causes these two diseases by using probiotics and other nutrients [5]. Dental schools and their continuing education departments will be forced to change in the near future. The practicing dentist can become involved with this shift through participating in new paradigm.

\section{References}

1. Fine JB, Yao SG (2007) The Influence of Periodontal Inflammation on Systemic Diseases and Medical Conditions. Access, publication of the American Dental Hygienists" Association.

2. Yao SG, Fine JB (2012) A Review of Vitamin D as It Relates to Periodontal Disease. Compendium of Continuing Education Dentistry 33(3): 166171.

3. Fine JB (2016) Inside dental Hygiene: Inflammation: The Oral/Systemic Link 12(1).

4. Yao SG, Fine JB (2010) Periodontitis and Cancer... A Link? A Review of the Recent Literature. Compend Contin Educ Dent 31(6): 436-442.

5. Yao SG, Fine JB (2014) Probiotics for Bacterial Disease Treatment in the Oral Environment. Compend Contin Educ Dent 35(9): 658-664.

\section{Your next submission with Juniper Publishers} will reach you the below assets

- Quality Editorial service

- Swift Peer Review

- Reprints availability

- E-prints Service

- Manuscript Podcast for convenient understanding

- Global attainment for your research

- Manuscript accessibility in different formats

( Pdf, E-pub, Full Text, Audio)

- Unceasing customer service

Track the below URL for one-step submission https://juniperpublishers.com/online-submission.php 